\title{
Teaching English through Online Learning (A Literature Review)
}

\author{
Dwi Suputra \\ Universitas Pendidikan Ganesha, Indonesia \\ dwisuputra4443@gmail.com
}

\begin{abstract}
The aim of this study is to investigate the teaching strategy to be implemented on teaching English through online learning. The design of the present study is a literature review design. Related studies about strategies on teaching English through online learning were analyzed in order to be described in present study. The findings of this present study show that teaching through videoconferencing, instant messaging, and game could be useful strategies on teaching English through online learning. Videoconferencing is found appropriate for enhancing oral interaction. Instant messaging is found appropriate for enhancing written interaction. Game is found appropriate for creating enjoyable learning atmosphere. There is high recommendation for teachers to use the strategy based on learning goal and situation. Teachers could utilize various ICT applications or platforms which support the implementation of the strategies.
\end{abstract}

Keywords: ICT, online learning, teaching strategy

\section{INTRODUCTION}

The implementation of English language teaching is affected by the learning environment. The term of learning environment traditionally refers to classroom, however it has been developed into term of distance learning (Altunay, 2019). Distance learning is teaching and learning process where teacher and students' interactions are facilitated with electronic, mechanical or other device (Moore \& Diehl, 2019). The origin of distance learning was started 1960s at the University of Tübingen (Moore \& Diehl, 2019), and it has been evolved into online learning (Siemens et al., 2015). The evolution of distance learning into online learning has affected by the advancement of Information and Communication Technology (ICT). The origin nature of learning anytime and anywhere certainly lies on online learning. The materials given could be accessed through information and communication technologies (Anderson, 2008; Garrison \& Anderson, 2003; Harasim, 2000).

Ghirardini (2011) mentioned that online learning is appropriate to use when learners have limited mobility. Occasionally, certain situations force learners to keep away from theirs school. At this situation, online learning becomes the answer to omit barrier of a distance since it offers the flexibility of learning (Clarke, 2004; Lipshitz \& Parsons, 2008). This opportunity of online learning then has been used for educational systems in Indonesia during Covid-19. Any activity causes a crowd during Covid-19 in Indonesia is abandoned. A crowd is mentioned as one cause of high distribution of Covid-19 virus. Since in-classroom setting causes crowd in schools, online learning setting has been used to avoid a crowd.

However, the massive implementation of online learning during Covid-19 in Indonesia is less followed by the readiness of its implementation. The sudden change from in-classroom setting to online learning setting affects the online 
learning readiness. Churiyah et al. (2020) revealed that the implementation online distance learning in Indonesia needs to be in terms of teachers' readiness in selecting the appropriate strategy. Amount of schools in Indonesia lack of experience in online learning since there unavailability of online learning regulation before (Priyanto, 2009). The regulation of online learning in Indonesia is mentioned in The Regulation of The Minister of Education and Culture Number 109 in 2013, however this regulation is just for tertiary education. The lack of experience then leads English teachers monotonously use the same technique for any occasion.

Nugroho, Ilmiani and Rekha (2021) found that low students' motivation is one EFL teachers' challenge in conducting online learning. It has been highlighted that the teachers teach monotonously which causes low students' motivation to learn. In teaching English through online learning, teachers need to design the online learning properly. The way to deliver the course in online learning is based on students' comfort with technology used, students' technical expertise to the technology used, and students' available time (Ghirardini, 2011). Teachers need to implement certain strategy to deliver English online course appropriately and attractively to students. If the way to deliver the course in online learning is appropriate and attractive to students, it would beneficial to motivate students to learn (Gonzalez \& St. Louis, 2018). Therefore, this study aims at identifying strategies in teaching English through online learning.

\section{METHOD}

The present study is literature review studies. A various studies related to online learning were analyzed to identify beneficial strategies to be implemented in teaching English through online learning. The studies were collected from online publishing studies and research. The main focus on the analysis was the effectiveness of using the strategies for English language learning through online learning, and additional information related to important points for implementing the strategies.

\section{FINDINGS \& DISCUSSIONS}

\section{Videoconferencing}

Videoconference strategy provides face-to-face interaction of teacherstudents and students-students (Rahayu, 2020), as the same in classroom interaction. Face-to-face interaction of videoconference is beneficial for the development of students' speaking skills. The findings by Loranc-Paszylk (2015) note that videoconferencing helped students developing speaking skills since it constructed oral interaction. Students are provided a model of spoken language by teachers. It would be opportunities for students to imitate and practice to speak. It is also noted in study by Fakhruddin (2018), where the students' speaking skills were comprehended through face-to-face interaction between students and teacher. When face-to-face interaction occurred between students and teacher, the students were enthusiastic to recite every sentence they heard. They subconsciously improve their speaking skills.

The implementation of videoconference strategy involves audiovisual interaction. It means that students and teacher's appearance, action, and voice are presented in the interaction. Kozar (2016) stated audiovisual interaction in videoconference which maintains key elements of communication process of the target language. Those key elements are the reception of non-verbal signs and 
the direct response. The non-verbal signs, such as gestures and facial expression, help to coordinate the interaction smoothly. In the other side, direct response provides real time process of input and output. Real time process of input and output of speech provided by videoconferencing could be modified into efficient interaction for group discussion and question and answer activity (Amin \& Sundari, 2020). It allows students to learn collaboratively.

There are important points if teachers want to implement videoconferencing strategy. Findings by Permatasari (2018) revealed that videoconferencing requires a stable internet connection. Teachers have to make sure if their students are in a location with a stable internet connection, or if their students' internet provider has a stable connection. Another that point that had been revealed that videoconferencing needs more internet quota. It is caused by audiovisual that consumes more internet quota. If teachers and students are capable to fill this requirement, it would be great opportunities for them to experience the benefits of videoconferencing strategy. There are several applications that could be utilize, such as Zoom, Google Meet, and Skype.

\section{Instant Messaging}

Daily activity of using smartphone for sending instant message could be seen as opportunities in education. It is beneficial to implement instant messaging strategy to develop students' writing skills in online learning environment. A study by Ahmed (2019) found that written interactions occur in instant messaging strategy. The nature of instant messaging, which is to send written interaction, was utilized to exchange each student's writing. The students learned from their friend's writing. Besides, the implementation of instant messaging would develop students writing skills in terms of natural interactions and contextualized language use (Winet, 2016). They would exchange ideas and communicate using English as the medium. It would be achieved if teacher maintains to use English in any activity of instant messaging.

Instant messaging is believed as an applicable strategy to be implemented. Lestiyanawati \& Widyantoro (2020) reported that instant messaging is an applicable since its implementation needs less internet quota. The applications, that support instant messaging strategy, are not merely to share students' writing. The applications could be utilized to share any material for students. Some applications that could be used in instant messaging strategy are WhatsApp, Telegram, and Line.

\section{Game}

The use of game in English Language Learning is beneficial to make students enjoy their learning. It is possible since game makes students attracted by its unique evaluation and feedback mechanism (Ma, 2018). The evaluation and feedback mechanism of game are interactively constructed with contextualized situation and challenging activity. It is different from common learning situation where students are conscious to interact and perform for learning purposes. In contrast, using game in English language learning gives enjoyable atmosphere for students (laremenko, 2017). This atmosphere indirectly motivates them to focus on completing their learning. A study by Gozcu \& Caganaga (2016) noted that the benefits of using game were giving satisfaction feeling, reducing anxiety, and leading to real context of language use. Game is constructed by interactive elements and activity which could give satisfaction feeling for students. It is useful 
to reduce students' anxiety to learn. Besides, game provides certain contextual elements where the language expression lies on it. It is helpful for students to observe the use of language in certain contextual occasion. Although game gives these benefits, teachers need to give more effort if they want to implement it (Zirawaga et al., 2017). Teachers have to be able to address the learning goal and lead students to reach it. Teachers could utilize several platforms, such as Kahoot, Quizizz, and Quizlet. If teachers want to give more effort, they could design and develop their own game.

\section{CONCLUSION}

Based on the finding and the discussion, teachers could use videoconferencing, instant messaging, and game as strategy to conduct their online learning. Each strategy has certain purposes to be implemented. Videoconferencing is useful if the learning focuses on oral communication, instant messaging is useful if the learning focuses on written communication, and game is useful if more enjoyable learning atmosphere wants to be created. It is highly recommended for teachers to implement the strategy based on students' capability on it.

\section{REFERENCES}

Ahmed, S. T. S. (2019). Chat and Learn: Effectiveness of Using Whatsapp as a Pedagogical Tool to Enhance EFL Learners' Reading and Writing Skills. International Journal of English Language and Literature Studies, 8(2), 6168. https://doi.org/10.18488/journal.23.2019.82.61.68

Altunay, D. (2019). EFL Students' Views on Distance English Language Learning in a Public University in Turkey. Studies in English Language Teaching, 7(1), 121. https://doi.org/10.22158/selt.v7n1p121

Amin, F. M., \& Sundari, H. (2020). EFL Students' Preferences on Digital Platforms during Emergency Remote Teaching: Video Conference, LMS, or Messenger Application? Studies in English Language and Education, 7(2), 362-378. https://doi.org/10.24815/siele.v7i2.16929

Anderson, T. (2008). Theory and practice of online learning (2nd ed.). AU Press.

Churiyah, M., Sholikhan, Filianti, \& Sakdiyyah, D. A. (2020). International Journal of Multicultural and Multireligious Understanding Indonesia Education Readiness Conducting Distance Learning in Covid-19 Pandemic Situation. International Journal of Multicultural and Multireligious Understanding (IJMMU), 7(6), 491-507.

Clarke, A. (2004). E-Learning Skills. MacMillan.

Fakhruddin, A. (2018). Using Google Meet in Teaching Speaking. Journal of English Language Learning, 2(2), 43-46.

Garrison, D. R., \& Anderson, T. (2003). Language learning in the 21st century. In Journal of the Communications Research Laboratory (Vol. 48, Issue 3). RoutledgeFalmer. https://doi.org/10.4018/ijvple.2019070104

Ghirardini, B. (2011). E-learning methodologies. Food and Agriculture Organization of the United Nations.

Gonzalez, D., \& St. Louis, R. (2018). Online Learning. In The TESOL Encyclopedia of English Language Teaching (1st ed.). John Wiley \& Sons, Inc. https://doi.org/10.4324/9780429355097-7

Gozcu, E., \& Caganaga, C. K. (2016). The Importance of Using Games in EFL Classroom. Cypriot Journal of Educational Sciences, 11(3). 
https://doi.org/10.18844/cjes.v11i3.625

Harasim, L. (2000). Shift happens: Online education as a new paradigm in learning. Internet and Higher Education, 3(1-2), 41-61.

laremenko, N. V. (2017). Enhancing English Language Learners' Motivation Through Online Games. Information Technologies and Learning Tools, 59(3), 126-133.

Kozar, O. (2016). Teachers' reaction to silence and teachers' wait time in video and audioconferencing English lessons: Do webcams make a difference? System, 62, 53-62. https://doi.org/10.1016/j.system.2016.07.002

Lestiyanawati, R., \& Widyantoro, A. (2020). Strategies and Problems Faced by Indonesian Teachers in Conducting E- Learning System During COVID-19 Outbreak. Journal of Culture, Literature, Linguistic and English Teaching, 2(1), 71-82.

Lipshitz, A. R., \& Parsons, S. P. (2008). E-learning: 21st century issues and challenges. In E-Learning: 21st Century Issues and Challenges. Nova Science Publishers.

Loranc-Paszylk, B. (2015). Videoconferencing as a Tool for Developing Speaking Skills. In Second Language Learning and Teaching. Springer. https://doi.org/10.1007/978-3-642-38339-7 12

Ma, K. (2018). The Application of Educational Games in English Teaching for NonEnglish Major Students. 8th International Conference on Education and Management, 75, 46-48. https://doi.org/10.2991/icem-18.2019.12

Moore, G. M., \& Diehl, W. C. (2019). Handbook of Distance Education (4th ed.). Routledge. https://doi.org/10.4324/9781315296135-3

Nugroho, A., Ilmiani, D., \& Rekha, A. (2021). EFL Teachers' Challenges and Insights of Online Teaching amidst Global Pandemic. Metathesis: Journal of English Language, Literature, and Teaching, 4(3). https://doi.org/10.31002/metathesis.v4i3.3195

Permatasari, Y. B. (2018). Male and Female Students' Perceptions Toward the Implementation of Video Conference As a Distance Learning Media That Enhances Teachers' Productivities. JALL (Journal of Applied Linguistics and Literacy), 2(2), 101. https://doi.org/10.25157/jall.v2i2.2194

Priyanto. (2009). Redesign of e-Learning Development in Indonesia. Journal for Vocational and Technical Education and Training, 9(1), 85-93.

Rahayu, D. (2020). Synchronous Zoom Web Conference System: An Exploratory Study on Students' E-Learning Experience. Journal of ELT Research, 5(1), 68-79. https://doi.org/10.22236/JER

Siemens, G., Gašević, D., \& Dawson, S. (2015). Preparing for The Digital University: A Review of The History and Current State of Distance, Blended, and Online Learning. In Preparing for The Digital University: A Review of The History and Current State of Distance, Blended, and Online Learning. https://doi.org/10.13140/RG.2.1.3515.8483

Winet, D. (2016). Mobile Instant Messaging in the ESL Writing Class. The Electronic Journal for English as a Second, 20(3), 1-6.

Zirawaga, V., Olusanya, A., \& Maduki, T. (2017). Gaming in education: Using games a support tool to teach History. Journal of Education and Practice, 8(15), 55-64. https://files.eric.ed.gov/fulltext/EJ1143830.pdf 